\title{
Life after the 'Dano-Trilogy': Legal Certainty, Choices and Limitations in EU Citizenship Case Law
}

\author{
Moritz Jesse and Daniel William Carter*
}

\section{Introduction}

Welfare entitlements of EU Citizens, especially those who are not economically active, were always controversial. This chapter will show that the European Court of Justice, in a line of cases starting with the Förster decision, ${ }^{1}$ started to develop quite coherent case-law based on Directive 2004/38, which linked equal treatment as regards social benefits to legal residence under Directive $2004 / 38 .^{2}$ Despite one or two exceptions, this approach was gradually consolidated in follow-up cases, such as Ziótkowski and later Dano. The decisions taken by the Court are of course always embedded in a complex mixture of legal and non-legal factors, which all have likely contributed to the Court's attitude and approach. ${ }^{3}$ However, it will be shown that the Dano judgment can be seen as a product of rather conventional evolution of case law after the adoption of Directive 2004/38, rather than a full-on departure from the pre-existing

* Dr. Moritz Jesse is Associate Professor of EU Law at Leiden Law School. Daniel William Carter is a PhD Fellow at Leiden Law School. This chapter is an updated and elaborate version of Carter D., Jesse M. (2018), The "Dano Evolution": Assessing Legal Integration and Access to Social Benefits for EU Citizens, European Papers 3(3): 1179-1208.

1 For example, see the difference between Davies, G. (2018). Has the Court changed, or have the cases? The deservingness of litigants as an element in Court of Justice citizenship adjudication. Journal of European Public Policy 25 (10), pp. 1442-146o, and Hoogenboom, A. (2018). CJEU case law on EU Citizenship: normatively consistent? Unlikely! A response to Davies "Has the Court changed, or have the cases?". EU Law Analysis, available at http://eulawanalysis.blogspot.com/2018/11/cjeu-case-law-on-eu-citizenship.html.

2 Thym, D. (2015). When Union citizens turn into illegal migrants: the Dano case. European Law Review 40(2), pp. 249-262.

3 Davies, G. (2018). Has the Court changed, or have the cases? The deservingness of litigants as an element in Court of Justice citizenship adjudication, cit., p. 1443; Šadl, U., and Sankari, S. (2017). Why did the Citizenship Jurisprudence Change? In: Thym, ed., Questioning EU Citizenship:Judges and Limits of Free Movement and Solidarity in the EU. Oxford: Hart Publishing. 
acquis. ${ }^{4}$ This development evolved into the much-discussed Dano-Trilogy of cases, ${ }^{5}$ which has caused quite a stir amongst academic commentators, despite limited effects in daily legal administration and practice. ${ }^{6}$ The Dano cases and its follow-ups were widely criticised for abandoning the Court's traditional stance of protecting EU citizens and furthering the value of Union citizenship by interpreting the law away from its market-based confines. ${ }^{7}$ That, either explicitly or implicitly, ${ }^{8}$ the Court has engaged in a "swift dismantling project" of the Union Citizenship acquis, ${ }^{9}$ and that through its decisions the Court is reacting to the current Zeitgeist by attempting to help quell the nationalist tide sweeping across Europe..$^{10}$ Another explanation included the changing

Nic Shuibhne, N. (2015). Limits Rising, Duties Ascending: The Changing Legal Shape of Union Citizenship. Common Market Law Review 52 (4), pp. 889-937, 907; Schiek, D. (2017). Perspectives on Social Citizenship in the EU: From Status Positivus to Status Socialis Activus via Two Forms of Transnational Solidarity. In: Kochenov, ed., EU Citizenship and Federalism: The Role of Rights. Cambridge: Cambridge University Press, pp. 36o-361.

$5 \quad$ This is defined as the series of cases concerning 'special non-contributory cash benefits', which runs through Court of Justice, judgment of 19 September 2013, case C-140/12, Brey; Court of Justice, judgment of 11 November 2014, case C-333/13, Dano; Court of Justice, judgment of 15 September 2015, case C-67/14, Alimanovic; Court of Justice, judgment of 25 February 2016, case C-299/14, García Nieto.

6 See Mantu S., and Minderhout, P. (2019) Exploring the Links between Residence and Social Rights for Economically Inactive EU Citizens. European Journal of Migration and Law 21, pp. 313-337, 316ff., 335 .

$7 \quad$ Nic Shuibhne, N. (2015). Limits Rising, Duties Ascending: The Changing Legal Shape of Union Citizenship. Common Market Law Review $5^{2}$ (4), pp. 889-937; O'Brien, C. (2017). The ECJ Sacrifices EU citizenship in vain: Commission v United Kingdom. Common Market Law Review, 54 (1), pp. 209-243; Spaventa, E. (2017). Earned Citizenship - Understanding Union Citizenship through Its Scope. In: Kochenov, ed., EU Citizenship and Federalism: The Role of Rights. Cambridge, Cambridge University Press.

8 See, amongst others, Van den Brink, M. (2019). The Court and the Legislators: Who Should Define the Scope of Free Movement in the EU? In: Bauböck, ed., Debating European Citizenship. Cham: Springer; Lenaerts, K. (2011). European Union Citizenship, National Welfare Systems and Social Solidarity.Jurisprudencia 18 (2), pp. 397-422; Thym, D. (2017). The Evolution of Citizens' Rights in Light of the European Union's Constitutional Development. In: Thym, ed., Questioning EU Citizenship - Judges and the Limits of Free Movement and Solidarity in the EU. Oxford: Hart Publishing; Nic Shuibhne, N. (2015). Limits Rising, Duties Ascending: The Changing Legal Shape of Union Citizenship, cit.; Davies, G. (2018). Has the Court changed, or have the cases? The deservingness of litigants as an element in Court of Justice citizenship adjudication, cit.

9 O'Brien, C. (2017). The ECJ Sacrifices EU citizenship in vain: Commission v United Kingdom, cit., p. 210.

10 Šadl, U., and Sankari, S. (2017). Why did the Citizenship Jurisprudence Change? In: Thym, ed., Questioning EU Citizenship: Judges and Limits of Free Movement and Solidarity in the EU. Oxford: Hart Publishing, p. 109; O'Brien, C. (2017). The ECJ Sacrifices EU citizenship in vain: Commission v United Kingdom, cit. 
nature of cases reacting the Court and the increasingly un-deserving nature of the applicants which have led to controversial decisions such as Dano and Alimanovic. ${ }^{11}$

This chapter will argue amongst a more orthodox, less political line to explain the Dano-Evolution: The three cases of the Dano-Trilogy are not the revolutionary cases that they are asserted to be. Instead, the developments both before and after Dano can be attributed to a natural evolution of the case-law following the introduction of Directive 2004/38. In this respect, it will be argued that the alleged "patchwork" of citizenship case-law is in fact rather coherent, ${ }^{12}$ the reasoning and outcomes of the judgments are on the whole convincing. ${ }^{13}$ In order words, setting aside the fractious normative and political arguments surrounding the cases, it will be claimed that legal developments can be explained as mostly logical and predictable evolution of the law. This 'evolution' can be best explained as 'interpretation cessat in claris', and conforms to the standard method of legal reasoning used by the Court. This dictates that so long as the wording of a legal text is clear, there is no reason to search for a more purposive or teleological meaning beyond its ordinary understanding. This is what has happened after the adoption of Directive 2004/38.14

Thereafter, the chapter will introduce some of the inevitable consequences of the new formalistic interpretation of Directive 2004/38 will have for economically active and not economically active EU Citizens. Also, the anatomy of a decrease of individualized proportionality tests and automatic tests of legal residence under the Directive, as well as the ever-broadening scope of social assistance and the range of social benefits that can be subjected to residence tests will be looked at.

It will be concluded that despite the problems associated with a strict interpretation of the Directive, particular for certain groups of EU Citizens, it has to be acknowledged that the Court is increasing legal certainty and predictability of judgments. The Court is accepting the political choices made by the EU legislature, and by applying such rules as laid down in secondary legislation, the

11 Davies, G. (2018). Has the Court changed, or have the cases? The deservingness of litigants as an element in Court of Justice citizenship adjudication. Journal of European Public Policy 25 (10), pp. 1442-146o, 1443.

12 O'Brien, C. (2017). United in Adversity: EU Citizenship, Social Justice and the Cautionary Tale of the UK. Oxford: Hart Publishing, p. 35 .

13 Neergaard, U. (2016). Europe and the Welfare State - Friends, Foes, or ...? Yearbook of European Law 35 (1), pp. 341-381, 377.

14 Lenaerts, K., and Gutiérrez-Fons, J.A. (2013). To Say What the Law of the EU is: Methods of Interpretation and the European Court of Justice. EUI AEL Working Papers 2013/9, p. 7 . 
Court is sticking to its standard method of legal reasoning. As such, any criticism of the legal situation of EU Citizens under Directive 2004/38, which may be valid and justified, may be better placed against the EU legislature rather than the judiciary.

\section{The Evolution that Led to the Dano-Triloygy}

1.1 The Early Cases: Martínez Sala, Baumbast, and Trojani

Accessing a Member State's "circle of solidarity" has never been open-ended or unconditional for economically inactive EU Citizens. ${ }^{15}$ Traditionally, workers, the self-employed, and their family members, were awarded equal treatment not only with regard to accessing employment and working conditions in the strict sense, but also with regard to all other social advantages enjoyed by domestic workers and Member State nationals, ${ }^{16}$ including accessing all manner of social benefits. Other categories of individuals moving throughout the EU were not granted such far-reaching equal treatment rights. ${ }^{17}$ Following the introduction of EU Citizenship in the Treaty of Maastricht, academic discussion was divided about its precise nature in this regard, and it took a while before the Court stepped into this discussion in the 199os with a series of judgments which defined the value of EU Citizenship. ${ }^{18}$

In Martínez Sala, the Court held that a Spanish national residing lawfully in Germany for over 20 years could not be denied equal treatment with regard

15 Verschueren, H. (2015). Preventing "benefit tourism" in the EU: A narrow or broad interpretation of the possibilities offered by the ECJ in Dano? Common Market Law Review 52 (2), pp. 363-39o, 364 .

16 Regulation (EEC) No 1612/68 of the Council of 15 October 1968 on freedom of movement for workers within the Community, OJ L 257, 19.10.1968, p. 2-12; See Plender, R. (2005). Citizenship and Immigration. European Business Law Review 16 (3), pp. 559-59o, 566-567.

17 This was the case even after the adoption of the 'Residency Directives': Directive 9o/364/ EEC of 28 June 1990 on the right of residence, OJ L 180, 13.7.199o, p. 26-27; Directive 68/36o/ EEC on the abolition of restrictions on movement and residence within the Community for workers of Member States and their families, OJ L 257, 19.10.1968, p. 13-16; Directive 93/ 96/EEC of the Council of 29 October 1993 on the right of residence for students, OJ L 317 , 18.12.1993, p. 59-6o; See Kostakopoulou, D. (1999). Nested "Old" and "New" Citizenships in the European Union. Columbia Journal of European Law 5 (3), pp. 389-414, 404-405.

18 For example, see Shaw, J. (1997). The Many Pasts and Futures of Citizenship in the EU. European Law Review 22 (6), pp. 554-572; Weiler, J. (1996). European NeoConstitutionalism: In search of Foundations for the European Constitutional Order. Political studies 44 (3), pp. 517-533; Kostakopoulou, D. (1996). Towards a Theory of Constructive Citizenship in Europe. Journal Political Philosophy 4 (4), pp. 337-358. 
to social (security) benefits in the form of a child benefit, ${ }^{19}$ solely because her residence permit granted on the basis of national law had expired and she was yet to receive a new one. In this seminal case, the Court first linked the freedom of EU Citizens to move and reside throughout the Union with the principle of equal treatment. ${ }^{20}$ The decision excited many commentators about the prospect of equal treatment being extended beyond the realms of economic activity and to arise solely on the basis of residence. ${ }^{21}$ At first, this seemed attainable, as the scope of Union Citizenship and the link between any kind of legal residence and equal treatment was extended further in the cases of $\mathrm{Ba}$ umbast and Trojani.

In Baumbast, even though no social benefit was at stake, the Court found a national measure rejecting a right of residence for Mr Baumbast's Colombian wife disproportionate, even though he arguably failed to meet the conditions laid down in the Residency Directive 9o/364. His health insurance did not cover all risks, as was technically required by this predecessor to Directive 2004/38. ${ }^{22}$ The Court held that he could nevertheless rely directly on Article $18 \mathrm{TEC}$ (Article $21 \mathrm{TFEU}$ ) to obtain a right to reside and consequently equal treatment. ${ }^{23}$ Baumbast showed that Directive 9o/364, a Directive adopted before EU Citizenship was introduced into the EC Treaty, did not limit the wider application of Article $18 \mathrm{TEC}$ to persons who arguably had no right of residence under secondary legislation.

The Court developed this line of argument further in Trojani, where a Frenchman residing in Belgium and working for the Salvation Army in return

19 Defined as a family benefit under Article 1(u)(i) Regulation 1408/71 on the application of social security schemes to employed persons and their families moving within the Community, OJ L 149, 5.7.1971, p. 2-50; see also Court of Justice, judgment of 12 May 1998, Case C-85/96, María Martínez Sala, para. 24.

20 Articles 8(2) EC (now Articles 20 \& 21 TFEU) and Article 6 EC (now Article 18 TFEU) respectively.

21 Shaw, J. (2010). A View of the Citizenship Classics: Martinez Sala and Subsequent Cases on Citizenship of the Union. In: Maduro and Azoulai, eds., The Past and Future of EU Law The Classics of EU Law Revisited on the $50^{\text {th }}$ Anniversary of the Rome Treaty. Oxford: Hart; see also Closa, C. (1992). The Concept of Citizenship in the Treaty of the European Union. Common Market Law Review 29 (6), pp. 1137-1169; Vincenzi, C. (1995). European citizenship and free movement rights in the United Kingdom. Public Law, pp. 259-275; Meehan, E. (1993). Citizenship and the new European Community. Political Quarterly 64 (2), pp. $172-186$.

22 Art. 1 Council Directive 9o/364/EEC of 28 June 1990 on the right of residence.

23 Court of Justice, judgment of 17 September 2002, C-413/99, Baumbast; See Timmermans, C. (2010). Martinez Sala and Baumbast revisited. In: Maduro and Azoulai, eds., The Past and Future of EU Law - The Classics of EU Law Revisited on the $50^{\text {th }}$ Anniversary of the Rome Treaty. Oxford: Hart p. $345^{-355}$. 
for 'pocket money', food, and shelter was denied access to the Belgian 'minimex' social assistance benefit. In its decision, the Court outlined three situations in which an application for social assistance must be granted. The first is if they can be classified as a worker and are engaged in 'genuine' economic activity. The second is if the individual has resided in the host-Member State for a "period of time" (à la Martínez Sala). Trojani added a third situation, where the individual was in possession of a residence permit granted on the basis of national law. This was held to be enough to demonstrate lawful residence also from the perspective of EU law, with all the benefits that that status entails. This again demonstrated that a right of residence could be established outside the conditions under applicable secondary legislation. As shall be seen, this far-reaching approach that blurs the distinction between national and EUbased residence, is now obsolete in the wake of Directive 2004/38.

Even during this period in which cases were mostly decided in favour of the applicants, the Court nonetheless reiterated the ability of Member States to protect their welfare system from unreasonable burdens posed by EU Citizens. In Baumbast, the Court emphasized that the whilst the preamble to Directive 9o/364 stated that individuals must not become an unreasonable burden on the host Member State, this was not the case with either Mr Baumbast or the members of his family. ${ }^{24}$ In Trojani, the Court again emphasised that the right to move and reside is not unconditional, and can be limited to ensure the EU Citizen has "sufficient resources to avoid becoming a burden on the social assistance system", ${ }^{25}$ even if Mr Trojani's specific situation was not considered. ${ }^{26}$ These formative cases emphasised the independent legal value of Union Citizenship by linking what is now Article $21 \mathrm{TFEU}$ directly with the right to equal treatment under Article $18 \mathrm{TFEU}$. National residence status was also linked with equal treatment, with primary law seemingly trumping both EU secondary legislation, which at the time proceeded the introduction of Union Citizenship, as well as national legislation, with any restriction having to be judged in the light of proportionality. ${ }^{27}$

\subsection{The Reign of Vague Legal Formulas: Grzelczyk, Bidar, and Brey}

The next wave of cases that reached the Court before the adoption of Directive $2004 / 38$ concerned a variety of categories of social benefits ranging from

24 Baumbast, cit., paras. $90-92$.

25 Court of Justice, judgment of 7 September 2004, Case C-456/o2, Trojani, para. 33.

26 Trojani, cit., paras. $32-33$.

27 Nic Shuibhne, N. (2015). Limits Rising, Duties Ascending: The Changing Legal Shape of Union Citizenship, cit. 
student loans to unemployment benefits. Whilst the legal environments which governed the access to these benefits were quite different, the Court dealt with this variety of social benefits in a surprisingly similar fashion. In Grzelczyk and Bidar, two cases which concerned the rights of students in accessing minimum subsistence benefits and student financing, ${ }^{28}$ the Court developed complicated formulae to test when individuals can access equal rights regarding access to social benefits and when such access can be denied. On paper, these formulas recognized the legitimate interest of Member States to protect the financial sustainability of their welfare systems. However, in practice they strengthened the position of individual applicants vis-à-vis the State, again arguably circumventing conditions contained in applicable secondary legislation. It should be noted that in the case of students, Directive 93/96 was adopted shortly before the Treaty of Maastricht entered into force in November 1993, and is slightly different from the situation in stage 1 where the relevant secondary law was adopted clearly before Maastricht.

Grzelczyk concerned a French student in Belgium claiming minimum subsistence assistance in the final year of his studies. Article 1 Directive 93/96 stated that students must assure national authorities that they were in possession of sufficient resources to avoid becoming a burden on the host-state's social assistance system, whilst Article 4 further stated that students would have a right of residence so long as these conditions were met. Despite this, the Court held that denying a right of residence could never be the 'automatic consequence' of a mere request of social assistance, ${ }^{29}$ and that the Member State in question must demonstrate 'a degree of financial solidarity' with the migrant, assuming the difficulties are temporary and the individual does not become an 'unreasonable' burden on the public finances of the host state. ${ }^{30}$ In doing so, the Court introduced a subtle distinction between burdens that could be considered 'reasonable' and those so 'unreasonable' as to break this bond of financial solidarity between the host-state and the migrant student, ${ }^{31}$ even if Belgium could in theory still revoke or refuse to renew Mr Grzelcyk's residence permit. ${ }^{32}$ However, the decision gave no real indication as to how to define the

\footnotetext{
28 Court of Justice, judgment of 20 September 2001, case C-184/99, Grzelczyk; Court of Justice, judgment of 15 March 2005, case C-209/03, Bidar.

29 Grzelczyk, cit., para. 43.

30 Grzelczyk, cit., para. 44 .

31 Kostakopoulou, D. (2007). European Union Citizenship: Writing the Future. European Law Journal 13 (5), pp. 623-646; O'Brien, C. (2017). United in Adversity: EU Citizenship, Social Justice and the Cautionary Tale of the UK, cit. 
terms 'unreasonable burden', 'automatic consequences', and 'temporary problems'. This was not helpful to national administrators, and created a constant threat as denying such an application for social assistance benefits who claim to be hit by temporary financial difficulties could be subsequently found to breach the bonds financial solidarity as it would not constitute an unreasonable burden in the particular case.

In Bidar, the Court reiterated that a 'genuine link' between the applicant and the host society which could expressed through a 'sufficient level' of integration, which would allow economically inactive students to access student financing in the host state. The UK rule, which required three years' residence to establish such a link was held in principle to be legal. ${ }^{33}$ However, it was too restrictive as it made it impossible for nationals of other Member States to demonstrate 'integration' in any way other than three years' residence. ${ }^{34}$ Assessing Mr Bidar's situation, the Court found that as he had undergone a significant portion of his secondary education in the UK, a 'genuine link' with British society could be established. ${ }^{35}$ Like in Grzelczyk, the Court did not define the terminology used. Authorities only knew that (1) three years' residence was not suitable as an exclusive category for determining a 'sufficient degree of integration'; and that (2) such a sufficient degree of integration existed after undergoing a significant portion of secondary education in the host state. Member States could theoretically protect their social assistance systems from unreasonable burdens by denying claims from individuals with an insufficient links to the host societies. However, the vague formulae provided by the Court always meant that they faced an elevated risk of violating EU law. ${ }^{36} \mathrm{~A}$ similar formula was constructed in the context of jobseekers' allowances under the free movement of workers, without any of the terminology being concretely defined. In Collins, the Court held that a period of working in the UK for 15 years before a claim for a jobseeker's allowance was lodged was too distant to establish a 'sufficiently close connection' with the UK's labour market. However, a 'genuine link' between the jobseeker and the employment market could be established through a 'reasonable period' of residence within which the candidate 'genuinely' sought work. ${ }^{37}$ This would oblige the Member State to

33 Bidar, cit., para. $5^{2}$.

34 Bidar, cit., para. 61.

35 Bidar, cit., paras. $60-62$.

36 Nic Shuibhne, N. (2016). What I tell you three times is true: Lawful Residence and Equal Treatment after Dano. Maastricht Journal of European and Comparative Law 23 (6), pp. 9o8-936, 920.

Court of Justice, judgment of 23 March 2004, case C-138/o2, Collins, para. 69. 
grant social benefits "intended to facilitate access to employment in the labour market". 38

The Court has intermittently used such an approach after the adoption of Directive 2004/38, with the most recent example being Brey, decided in 2013. ${ }^{39}$ It is argued here that this case is more of an outliner inspired by the older purposive approach of the Court. The case concerned yet another form of social benefit, this time a pension supplement, however, the Court used the same vague formulae to determine its accessibility. Austria rejected the claim of retired German couple, stating that that they did not have legal residence under Directive 2004/38 due to their insufficient income. In its judgment, the third chamber of the Court emphasised the link between Article 7 Directive 2004/38 and the requirement not to rely on welfare benefits in the country of residence. However, it also stated the common dictum that an 'automatic' denial of social assistance based on the presumption of insufficient resources is not permitted. Instead, the Member State in question must assess on a case-by-case basis whether an individual places an unreasonable burden on the welfare system of the state as a whole, by reference to the personal circumstances of the individual, and must comply with the principle of proportionality. ${ }^{40}$ This therefore required national authorities to assess every single claim, even during the first three months of residence where Directive 2004/38 rules out social assistance, ${ }^{41}$ against the impact such granting would have on the financial stability of the national welfare system overall. The formula put a heavy burden on the Member States and authorities while handing a significant advantage to individual applicants, and presupposed assessments that many (decentralized) administrations in charge of granting social benefits will find impossible to perform in practice. ${ }^{42}$ Brey was rendered by the Third Chamber of the Court in the year 2013 and seems out of place compared to subsequent developments. By 2014 the Grand Chamber of the Court had already moved on and adjusted

$38 \quad$ Collins, cit., para. 63 .

39 Minderhoud P., and Mantu, S. (2017). Back to the Roots? No Access to Social Assistance for Union Citizens who are Economically Inactive. In: Thym, ed., Questioning EU Citizenship Judges and the Limits of Free Movement and Solidarity in the EU. Oxford: Hart Publishing, p. $197-198$.

$40 \quad$ Brey, cit., para. 63-64.

41 Art. 6 Directive 2004/38/EC on the right of citizens of the Union and their family members to move and reside freely within the territory of the Member States.

42 Nic Shuibhne, N. (2015). Limits Rising, Duties Ascending: The Changing Legal Shape of Union Citizenship, cit.; O'Brien, C. (2017). United in Adversity: EU Citizenship, Social Justice and the Cautionary Tale of the UK, cit., p. 49; see also O'Brien, C. (2017). The ECJ Sacrifices EU citizenship in vain: Commission $v$ United Kingdom, cit., p. 216. 
its approach not only in Dano but also in Förster and Ziolkowski. This suggests that Brey is the 'swansong' of the Court's old qualitative approach, sang solely by the Third Chamber, rather than a signal of continuity of the orthodox approach. ${ }^{43}$

\subsection{The Turning Point toward Legal Certainty: Förster}

Directive 2004/38/EC had the purpose of unifying the fragmented legal landscape consisting of several Directives and Regulations for various groups of EU citizens into one coherent piece of legislation. ${ }^{44}$ Furthermore, it sought to codify case-law interpreting the rights of EU Citizens, which was mostly interpreting treaty provisions directly. At the same time it must also be seen as the expression of the EU legislator fulfilling its role under Articles 20 and $21 \mathrm{TFEU}$ to adopt secondary legislation providing for the enjoyment, but also for the limitation and conditions of free movement rights, as opposed to preexisting Directives. It was adopted specifically on the Union Citizenship and Equal Treatment bases, giving further effect to these primary law rights. We argue here that the Court of Justice effectively took the adoption of Directive $2004 / 38$ as opportunity to review and adjust its case-law. This is akin to what happened in the first step described above, albeit the mirror image of the early cases of the Court, when the Court took the introduction of Union Citizenship as an occasion to re-define its approach to free movement in the light of newly established Treaty provisions. The first opportunity the Court had to do this reversal was the Förster case rendered in 2008, although the facts of the case took place prior to the adoption and transposition of Directive 2004/38.45

Jacqueline Förster was a German national who had studied in Amsterdam. Because she was working, she was able to claim Dutch study benefits as she was an EU worker and therefore entitled to all 'social advantages' under Article 7(2) Regulation 1612/68. However, during a regular check at a later stage of her studies the Dutch authorities discovered that Ms Förster was not employed for a short period of time and asked her to re-pay the benefits she received during

43 Nic Shuibhne, N. (2015). Limits Rising, Duties Ascending: The Changing Legal Shape of Union Citizenship, cit., p. 892, 905-907; Schiek, D. (2017). Perspectives on Social Citizenship in the EU: From Status Positivus to Status Socialis Activus via Two Forms of Transnational Solidarity, cit., p. 36o-361.

44 As stated in the Directive, it amends Regulation (EEC) No 1612/68 on freedom of movement for workers within the Community and repeals Directives 64/221/EEC, 68/36o/EEC, 72/194/EEC, 73/148/EEC, 75/34/EEC, 75/35/EEC, 9o/364/EEC, 9o/365/EEC and 93/96/EEC.

45 See for more information on the case Golynker, O. (2009). Case C-158/o7, Jacqueline Förster v. Hoofddirectie van de Informatie Beheer Groep, Judgment of the Court (Grand Chamber) of 18 November 2008. Common Market Law Review 46 (6), pp. 2021-2039. 
these months. Relying on the Bidar case, Ms Förster argued that she had a sufficient degree of integration and genuine links with the Netherlands and could not be obliged to repay the benefits received. The case seemed an appropriate opportunity to merge the elements of allowing for access to social benefits because of a 'certain degree of integration' known from Bidar with the elements of temporal financial solidarity known from Grzelczyk. ${ }^{46}$ However, this did not happen. Instead, the Court dramatically changed the substance of the 'certain degree of integration' test to access the welfare system of the host-Member State as an economically inactive student, while the very wording of the test used by the Court stayed exactly the same. In Bidar, three years' residence was just one indicator allowed to consider if a genuine link existed. In Förster, the Court accepted the Dutch rule defining five years' legal residence as the only way of proving a sufficient degree of integration. This condition was by itself held proportionate to the legitimate aim of guaranteeing a genuine link. ${ }^{47}$

In its reasoning, the Court signalled the importance of permanent residence under Article 16(1) Directive 2004/38, which also requires five years of legal and continuous residence, even though the Directive was not applicable to the facts of the case. ${ }^{48}$ It is remarkable that the Court was able to shift from a qualitative to a quantitative test that assumes a sufficient level of integration only after five year's residence without changing one word in how the reasoning is formulated. ${ }^{49}$

Rather, by linking it to the Directive, it was the entire meaning of the concepts that changed. The decision meant in practice that students needed to either be economically active or have permanent residence status under Article 16(1) of the Directive before they were entitled to student grants and loans. This decision by the Court immediately created more legal certainty and made things much easier for national administrators. It also signalled to Member States that a strict word-for-word transposition of the Directive including restrictions to access public benefits for students would not be struck down by

46 On this issue, see Jesse, M. (2011). The Legal Value of 'Integration' in European Law. European Law Journal 17 (1), pp. 172-189; O'Leary, S. (2009). Equal Treatment and EU Citizens: A new chapter on cross-border educational mobility and access to student financial assistance. European Law Review 34 (4), pp. 612-627; see also Hoogenboom, A. (2018). CJEU case law on EU Citizenship: normatively consistent? Unlikely! A response to Davies "Has the Court changed, or have the cases?", cit.

47 Förster, cit., paras. $5^{2-54}$.

48 Förster, cit., para. 55 .

49 Jesse, M. (2011). The Legal Value of 'Integration' in European Law, cit.; O'Leary, S. (2009). Equal Treatment and EU Citizens: A new chapter on cross-border educational mobility and access to student financial assistance, cit., p. 622 . 
the Court on the basis of primary EU law and earlier decisions such as Bidar. The rules as contained in the Directive, particularly those relating to permanent residence and student financing were a key part of the political compromise leading to the Directive's adoption..$^{50}$ As later case-law has shown, this promise was lived-up to by the Court.

\subsection{The (New) Dominance of Directive 2004/38: Ziółkowski \& Szeja}

The next step in our evolution was Ziótkowski \& Szeja, decided in 2011 and which concerned the nature of the newly established permanent residence status under the Directive. ${ }^{51}$ In particular it threw light on the issue of which forms of residence gives access to permanent residence rights under Article 16(1), and whether the qualifying residence period of five years could have started before Directive 2004/38 had entered into force and transposed by Member States, or even before the EU Citizen's Member State of origin joined the EU. The Court had already established previously in Lassal that residence completed "in accordance with earlier European Union law instruments" should be considered when determining whether there has been five years residence under Article 16(1).52 However, Ziótkowski \& Szeja concerned the relationship between Article 16(1) permanent residence and residence on the basis of national humanitarian law, even though the applicants were economically inactive and did not have sufficient resources under Article 7. In his Opinion, the Advocate General cited the Court's reasoning in Dias, ${ }^{53}$ which stated that permanent residence under Directive 2004/38 was above all a tool to assist with the integration of EU Citizens in the host Member State. In his opinion, this meant that length of residence on the basis of national law as well as EU law should be considered, as well as taking into account other 'qualitative factors. ${ }^{4}$

However, the Court continued on the path of a more textual, formalistic interpretation of the Directive. Instead of accepting at all types of legal residence under EU and national law, the Court held that the definition of 'legal' and 'continuous' residence for 5 years under Article 16(1) of the Directive must

50 See Jesse, M. (2012). Joined Cases C-424/10, Tomasz Ziótkowskiv. Land Berlin, and C-425/10, Barbara Szeja, Maria-Magdalena Szeja, Marlon Szeja v. Land Berlin. Common Market Law Review 49 (6), pp. 2003-2017.

51 Court of Justice, judgment of 21 December 2011, joined cases C-424/10 and C-425/10, Ziótkowski \& Szeja.

$5^{2}$ Court of Justice, judgment of 7 October 2010, case C-162/og, Lassal, para. 40.

53 Court of Justice, judgment of 21 July 2011, case C-325/o9, Dias, para. 64; Opinion of Advocate Genera Bot delivered on 14 September 2011, joined cases C-424/10 and C-425/10, Ziótkowski \& Szeja, para. 53 . Opinion of Advocate Genera Bot, Ziótkowski \& Szeja, cit., paras. 53-54. 
be interpreted autonomously from national law. There is, after all, no reference to national law in Articles 7 or 16(1) of Directive 2004/38. Hence only residence in conformity with Article 7 of the Directive can lead to permanent residences status under Article 16(1). This includes, however, periods of residence in compliance with the conditions mentioned in Article 7 before the entry into force of the Directive and even before the accession of new Member States. ${ }^{55}$ In Ziótkowski, the applicants could not prove that they had sufficient resources in the 5 -year period before requesting permanent residence, hence their residence did not comply with the conditions of Article 7 of the Directive and permanent residence under Article 16(1) could not be established.

Neither the Advocate General nor the Court mentioned the Förster judgment in Ziótkowski. Others have therefore marked Ziótkowski and not Förster as the turning point from a 'rights-opening' to a 'rights-closing approach' only. ${ }^{56}$ Yet, it is our claim that both cases form a continuum. The absence of Förster in Ziótkowski may be because the subject matter in each case was different, or because, at least officially, the Directive did not yet apply in Förster. Whilst Förster dealt with student grants, it did touch upon permanent residence under Directive 2004/38 indirectly as five years of legal residence was the only way under Dutch law to show the required 'degree of integration'. However, the seeds sowed in Förster in 2008 fell on fertile ground in Ziótkowski, which confirmed the closed system to define the conditions for legal residence and resulting equal treatment exclusively on Directive 2004/38. After these two judgments the Directive emerged as the only frame within which the Court establishes legality of residence of EU Citizens. In Förster, this link was more indirect, by validating Dutch law which transposed the Directive. ${ }^{57}$ In both cases, however, only the Directive and the choices made by the EU legislator therein were looked at to determine the status of the applicant in a distinct departure from

55 Ziótkowski \& Szeja, cit., para. 63; see also Jesse, M. (2012). Joined Cases C-424/10, Tomasz Ziótkowski v. Land Berlin, and C-425/10, Barbara Szeja, Maria-Magdalena Szeja, Marlon Szeja v. Land Berlin, cit.

56 Šadl, U., and Sankari, S. (2017). Why did the Citizenship Jurisprudence Change?, cit., p. 91; Nic Shuibhne, N. (2015). Limits Rising, Duties Ascending: The Changing Legal Shape of Union Citizenship, cit., p. 917.

57 In para. 55 of the Förster judgment the Court explicitly discusses permanent residence in the context of Article 24(2)of the Directive: 'Directive 2004/38 (...) provides in Article $24(2)$ that, in the case of persons other than workers, self-employed persons, persons who retain such status and members of their families (i.e. students) the host Member State is not obliged to grant maintenance assistance for studies, including vocational training, consisting in student grants or student loans, to students who have not acquired the right of permanent residence'. 
the above mentioned pre-Förster jurisprudence on Union Citizenship. After these two judgments, the Dano-Trilogy was the inevitable next step.

\subsection{The Inevitable and Logical Next Step: Dano, Alimanovic, and Garcia Nieto}

Our final step is the Dano case and subsequent decisions of the Court. In Dano, the Court allowed Germany to refuse social minimum assistance benefits for an unemployed Romanian mother, because she did not meet the conditions for legal residence in Article 7 Directive 2004/38. She was neither a worker nor did she have sufficient resources at her disposal. Therefore, she could not rely on the right to equal treatment under Article 24(1). ${ }^{58}$ Simply put, Dano confirmed that individuals cannot claim equal treatment under Article 24 unless they have a right to reside under Article 7 of Directive 2004/38, at least within the first 5 years of their residence in the host Member State. ${ }^{59}$ As in Ziótkow$s k i$, the Court assessed legal residence and equal treatment rights exclusively within the framework created by Directive 2004/38. It declined to consider any potential quantitative or qualitative factors or 'links' between Ms Dano and Germany outside of the Directive.

After Förster and Ziótkowski, the judgment in Dano was inevitable. If Union Citizens, after Ziótkowski, need to comply with the conditions laid down in Article 7 Directive 2004/38 in order to obtain long-term residence status under Article 16(1), then it stands to reason that they must comply with the conditions of Article 7 during the initial 5 year period of residence if they wish to claim equal treatment and social benefits under the same legal instrument. Separate concepts of legal residence for the purposes of Articles 6, 7, 16(1), and/or 24 of Directive 2004/38 would be detrimental to legal certainty and coherence, which the Directive was meant to introduce. Put in simple terms, after Förster, Ziótkowski, and Dano, access to permanent residence, legal residence, and equal treatment, including access to social benefits for economically inactive EU citizens, depends entirely on the same form of legal residence under Directive 2004. Primary EU law effectively plays no more role in this regard.

The Court followed the same logic in 2015 in Alimanovic. ${ }^{60}$ The case concerned a Swedish mother and her daughters, who returned to Germany in 2010

\footnotetext{
$5^{8}$ Dano, cit., para. 82.

59 Thym, D. (2015). When Union citizens turn into illegal migrants: the Dano case. European Law Review 4o(2), pp. 249-262; Nic Shuibhne, N. (2015). Limits Rising, Duties Ascending: The Changing Legal Shape of Union Citizenship, cit.

60 Alimanovic, cit.
} 
after some years' absence. They worked intermittently for 11 months before they lodged an application for social minimum subsistence benefits. ${ }^{61}$ The question was whether, as jobseekers who were formerly employed years ago and for 11 months just prior to their application, they should retain the status of worker, or be treated as jobseekers. Against the advice of Advocate General Wathelet, ${ }^{62}$ the Court upheld the link made in Dano between residence in conformity with Article 7 and equal treatment under Article 24(1) of the Citizens' Directive. As in Dano and Ziótkowski, their residence and equal treatment rights were assessed under the Directive only, with primary EU law playing no role. The Court then proceeded to apply the rules on retaining worker status as laid down in the Directive. According to Article 7(3)(c) Directive 2004/38, Union citizens retain the status of worker for a minimum of 6 months, after employment of less than 12 months. Hence Ms Alimanovic and her daughter could not retain worker status for longer than 6 months. Whilst they still could reside as a jobseeker under Article 14(4)(b), the express derogation in Article 24(2) allowed Germany to deny them social assistance. Whilst not decisive in the case itself, the Court also established a new test for determining what is an 'unreasonable' burden under the Directive. It moved away from a duty to establish that each individual claim of social security benefits would amount to an unreasonable burden, and instead held that "while an individual claim might not place the Member State concerned under an unreasonable burden, the accumulation of all the individual claims which would be submitted to it would be bound to do so".63

The final case of the Dano-Trilogy is Garcia Nieto ${ }^{64}$ The case concerned two Spanish nationals that moved to Germany in 2012. The couple were neither married nor in a civil partnership, but did have a child together. The mother moved in April 2012 with their common child in order to work, whilst the father moved in June of the same year with his child from a previous relationship. After arriving in Germany, the father applied for a minimum subsistence social assistance under the German Social Law, i.e. the Hartz-4 benefit under the German Social Code II (SG B II), the same social benefits as in Dano, from July until September. His claim was denied because he had not been residing

61 See also the excellent summary by Nic Shuibhne, N. (2016). What I tell you three times is true: Lawful Residence and Equal Treatment after Dano, cit., p. 911-913.

62 Opinion of Advocate General Wathelet delivered on 26 March 2015, case C-67/14, Alimanovic, paras. 99-109.

63 Alimanovic, cit., para. 62.

64 García Nieto, cit. 
in Germany for longer than three months. ${ }^{65}$ The Court held that father and son were not entitled to this social assistance benefit as Article 24 Directive 2004/38 contained an explicit derogation whereby the host Member State is not obliged to grant social assistance during the first three months of residence. ${ }^{66}$ The Court emphasized, as did the Advocate General, ${ }^{67}$ that this limitation according to Recital 10 of the Directive seeks to maintain the "financial equilibrium of the social assistance systems of the Member States". 68 The Court also makes a link with the system of retention of worker status in Alimanovic, asserting that Directive 2004/38 approach by confirming that the German rule excluding such persons from social assistance claims guarantees a "significant level of legal certainty and transparency ... while complying with the principle of proportionality". ${ }^{69}$ The Court here also confirms the new approach taken in Alimanovic to determining what is an unreasonable burden. ${ }^{70}$

After these initial three cases, the Court has followed its line and remained answering questions posed about Citizenship of the Union exclusively through a textual interpretation of Directive 2004/38 as when they fall within the scope of application of the Directive. ${ }^{71}$ This has been done, for example, in Diallo, to limit the rather lose interpretation of procedural deadlines in the Directive the Belgian State had in place, ${ }^{72}$ or Tarola, about retention of worker status after becoming involuntary unemployed after a short period of work only. ${ }^{73}$ Also in many cases of return, where the Directive is not applicable as such, the Court referred to it as frame of reference in analogy. ${ }^{74}$

65 It should also be noted that mother and common child were entitled to such benefits due to the mother's economic activity, however, father and son were not seen as 'family members' deriving rights under the Directive.

66 García Nieto, cit., para. 44.

67 Opinion of Advocate General Wathelet delivered on 4 June 2015, case C-299/14, García Nieto, para. 70 .

68 García Nieto, cit., para. 45.

69 García Nieto, cit., para. 49.

70 García Nieto, cit., para. 50.

71 See for an updated commentary on case-law of the CJEU in, inter alia, the fields of EU Citizenship and free-movement rights, Van den Bogaert, S., Jesse, M. et al. (2019). Kroniek van het Europees materieel recht. Nederlands Juristen Blad 10.

72 Court of Justice, judgment of 27 june 2018, case C-246/17, Diallo v. Belgium.

73 Court of Justice, judgment of 11 april 2019, case C-483/17, Tarola v. Ireland.

74 See for example Court of Justice, judgment of 12 July 2018, case C-89/17, Banger $v$. VK, or Court of Justice, judgment of 27 June, 2018, case C-230/17, Deha-Altiner \& Ravn v. Denmark. 


\subsection{Constitutional Aspects and the Relationship between Primary and Secondary Law over Time}

After describing the evolution of case law throughout the above mentioned five steps, it is necessary to reflect on the changing legal framework for EU Citizenship during this period. The Court has had to define the temporal and constitutional relationship between pre-existing secondary EU law, ${ }^{75}$ the provisions on Union Citizenship, ${ }^{76}$ as well as Directive 2004/38. The introduction of EU Citizenship in 1993 did not immediately lead to a revision of pre-existing secondary law by the EU legislator. As such, it was not until 2004 that the full range of rights and conditions applicable to EU Citizens was codified. Beforehand, the Court was required to "fill out" the Treaty provisions on EU Citizenship and define their precise relationship with secondary pre-existing secondary legislation in its acquis, ${ }^{77}$ as has been shown above in Steps 1 and 2. The Court did not overrule existing secondary law or bluntly ignored it. Instead, it merely adopted its case-law to a new legal situation after the introduction of the primary law rights contained in the provisions on EU Citizenship through a teleological interpretation of the law. ${ }^{78}$ What happened in Steps 3,4 , and 5 with and after the Förster and Ziótkowski cases is the mirror image to this development. Directive 2004/38 was adopted on a host of legal bases, inter alia Article 18 TEC (now Article 21 TFEU), and concerns the rights and obligations of all EU Citizens. The Directive codified parts of the Court's case-law and also introduced new ideas and wishes of the EU legislator, such as those of permanent residence status and a specific provision on equal treatment. ${ }^{79}$ Such notions are absent from the pre-existing Directives as well as the primary law provisions on Union Citizenship. ${ }^{80}$ Directive 2004/38 is therefore much clearer in defining the precise status and rights, including equal treatment rights, of all European migrants, which were the result of the Union's (albeit imperfect) democratic decision making process, ${ }^{81}$ at least when compared to the loose

\footnotetext{
75 In particular, the Residency Directives 9o/364/EEC; 68/36o/EEC; and 93/96/EEC.

76 See above steps 1 and 2 .

77 Lenaerts, K., and Gutiérrez-Fons, J.A. (2013). To Say What the Law of the EU is: Methods of Interpretation and the European Court of Justice, cit., p. 25.

78 See for example, Nowak, T. (2018). The rights of EU Citizens: a legal-historical analysis. In: Van der Harst et al., ed., European Citizenship in Perspective. Cheltenham/ Northhampton MA: Edward Elgar.

79 Art. 16(1) Directive 2004/38, plus Recital (17); Article 24 Directive 2004/38.

8o With the exception of the Revised Student Residency Directive 93/96/EEC of the Council of 29 October 1993 on the right of residence for students.

81 Van den Brink, M. (2019). The Court and the Legislators: Who Should Define the Scope of Free Movement in the EU?, cit., p. 134.
} 
combination of primary law rights combined with pre-existing secondary legislation. From this perspective it is logical that the new legal situation after the adoption of Directive 2004/38 would influence the evolution of the case law. Just like after the introduction of Union Citizenship, a new legal environment new was created, and the Court took note and adjusted its approach accordingly, shifting towards a more formal, strict reliance on the wording of the Directive.

This is not a radical departure from the Court's traditional approach to legal reasoning, but rather its explicit, albeit largely theoretical, approach. ${ }^{82}$ This is based on the 'classic' textual, contextual, and purposive approach applied by other national courts. ${ }^{83}$ This suggests that, assuming the ordinary meaning of the text is clear, that the Court need not develop further contextual or teleological interpretations of the law. That being said, the Court of Justice is not always consistent in the weight or ranking it gives to textual or purposive interpretations, and whether it has relied purely on the wording of the text in question, or primarily purposive criteria. ${ }^{84}$ However, the Court broadly applies the same reasoning as other courts, and contrary to what some commentators suggest, evidence from its case-law suggests that it does focus most heavily on textual arguments when deciding cases, a trend which has increased significantly in recent years. ${ }^{85}$ The Court's approach must therefore be seen as part of this overall trend.

A strict literal interpretation of the law is not unproblematic. It ignores the context and real-life consequences of individual cases, as well as the social or historical circumstances behind the adoption of the text, including the weight given to multiple purposes associated with it, and the context in which the applicable word or phrase is placed. As such, a level of purpose is inherent when interpreting any legal rule. ${ }^{86}$ In fact, even in Dano the Court felt the need to look at the purpose of Article 7 of the Directive, which is intended to prevent persons from becoming an unreasonable burden. ${ }^{87}$ This is suggested to

82 Lenaerts, K., and Gutiérrez-Fons, J.A. (2013). To Say What the Law of the EU is: Methods of Interpretation and the European Court of Justice, cit.

83 Beck, G. (2013). The Legal Reasoning of the Court of Justice of the EU. Oxford: Hart Publishing, p. 281.

84 Ibid, p. 280-283.

85 Ibid, p. $285^{-287}$.

86 Schlag, P. (2018). On Textualist and Purposivist Interpretation (Challenges and Problems). In: Perišin and Rodin, eds., The Transformation or Reconstitution of Europe: The Critical Legal Studies Perspective on the Role of the Courts in the European Union. Oxford: Hart Publishing, p. 19, 24-27.

87 Dano, cit., para. 71. 
deviate from other situations in which the Court has considered the purpose of Directive 2004/38. ${ }^{88}$ However, to stray too far away from the ordinary meaning of the Directive's rules would effectively ignore its adoption entirely and could create a situation where no social benefits could ever be denied from EU migrants. ${ }^{89}$ It would also run counter to the principles of legal certainty and inter-institutional balance enshrined in Article 13(2) TEU. ${ }^{90}$ It sometimes seems that the Court is criticised simply for giving meaning to Directive 2004/38. For example, it is suggested that the Court has contributed towards the more widespread and sustained recent shift from a "predominantly rights-opening to predominantly rights-curbing assessments of citizenship rights". ${ }^{91}$ This is expanded upon by Shuibhne in more detail: "the Court poured the content of the primary right to equal treatment into a statement in secondary law. That method turns the standard approach to conditions and limits on its head - the latter no longer temper equal treatment rights; they constitute the rights". ${ }^{92}$ Under this perspective, the Directive is brought up to 'constitutional level', and yet the Court does not apply a constitutional level review because it fails to review the legitimacy of legislative acts vis-à-vis the Treaty and wider general principles. As such, it is no longer clear that individuals residing on the basis of national law, but not EU law, will be able to benefit from equal treatment rights outside the Directive. In simple terms, the criticism is that the Court seems to have abandoned its case law based on primary EU law because of provisions found in secondary EU law, i.e. Directive 2004/38, an inferior source of law to the Treaties. ${ }^{93}$

The problem with such criticism is that the primary EU law itself explicitly mentions that Union Citizens can only exercise their rights "in accordance with the conditions and limits defined by the Treaties and by the measures adopted thereunder" ${ }^{94}$ Free Movement rights are "subject to the limitations and conditions laid down in the Treaties and by the measures adopted to give

88 Thym, D. (2015). The Elusive Limits of Solidarity: Residence Rights of and Social Benefits for Economically Inactive Union Citizens. Common Market Law Review 52 (1), pp. 17-50, 25.

89 Van den Brink, M. (2019). The Court and the Legislators: Who Should Define the Scope of Free Movement in the EU?, cit., p. 134.

9o Lenaerts, K., and Gutiérrez-Fons, J.A. (2013). To Say What the Law of the EU is: Methods of Interpretation and the European Court of Justice, cit., p. 7 .

91 Nic Shuibhne, N. (2015). Limits Rising, Duties Ascending: The Changing Legal Shape of Union Citizenship, cit., p. 902.

92 Ibid, p. 9o9-910.

93 Ibid, p. 915; O'Brien, C. (2017). United in Adversity: EU Citizenship, Social Justice and the Cautionary Tale of the $U K$, cit.

Article 20 last sentence TFEU, ex art. 17 TEC. 
them effect" ${ }^{\prime 5}$ Both Articles 20 and 21 TFE U suggest that the Directive merely fulfils its constitutional role laid down in the Treaties in defining the conditions and limitations under which EU Citizens can move. This is different to the pre-existing secondary legislation which did not "give effect" to such primary rights. In other words, within the clear mandate given to the EU legislator in the Treaties, and on the basis of all legal bases related to the free movement of persons, the Directive comprehensively covers residency and equal treatment rights, as well as the limits thereof for all groups of EU Citizens moving to another Member State. It is therefore the explicit objective of the Directive to codify and harmonise the precise conditions for the enjoyments of free-movement rights of all EU Citizens as laid down in the Treaties. The Directive effectively sets a floor of minimum standards that the Member States must abide by, e.g. providing for six months' retained worker status after a period of less than 12 months employment, ${ }^{96}$ but will allow the Member States discretion to go beyond this once they meet these minimum conditions. ${ }^{97}$ Crucially, however, Member States cannot be forced to do so based on case law preceding the Directive. A different approach in the line of cases starting with Förster and ending with the above mentioned 'Danotrilogy' based on earlier case law would have meant that the Court would have gone against the exact wording of Directive 2004/38, which has to be seen as the expression of the EU legislator based on a firm mandate in the Treaties. ${ }^{98}$ It would be strange for the Court to act as if this did not exist by relying on case-law from the preceding era. If this was the standard of judicial review in the future, the room of manoeuvre for the EU legislator would be significantly limited. Bearing these legal facts in mind, it seems unfair to solely criticise the Court for applying the law of the land in the form of Directive 2004/38, albeit strictly, rather than the EU legislator for adopting the Directive in its current form.

95 Article 21 TFEU, ex 18 TEC.

96 See article 7(3) Directive 2004/38; as was at issue in Alimanovic. See also O'Brien, C., Spaventa, E., and De Coninck, J. (2015). The concept of worker under Article 45 TFEU and certain non-standard forms of employment. Project Report, Brussels: European Commission. See Article 37, Directive 2004/38 explicitly states that it shall not affect any laws, regulations or administrative provisions "which would be more favourable to the persons covered by this Directive".

98 Thym, D. (2017). The Evolution of Citizens' Rights in Light of the European Union's Constitutional Development. In: Thym, ed., Questioning EU Citizenship - Judges and the Limits of Free Movement and Solidarity in the EU. Oxford: Hart Publishing; Van den Brink, M. (2019). The Court and the Legislators: Who Should Define the Scope of Free Movement in the EU?, cit. 


\subsection{Interim Conclusion: Evolution, Not Revolution}

The five-step evolution of the case-law leaves Union Citizens in the following position: First, access to equal treatment, including social benefits, and access to permanent residence depend on legal residence. Second, legal residence is exclusively determined with reference to Directive 2004/38. In other words, without legal residence under Article 7 Directive 2004/38, with very limited exceptions, ${ }^{99}$ neither equal treatment nor permanent residence can be successfully claimed. Third, the Dano 'revolution' was an example of a quite ordinary evolution of judicial interpretation. This evolution began with the Förster judgment, when the Court first started to assess the legal situation of applicants exclusively within the system created by Directive 2004/38 itself, and continued with Ziótkowski, Dano, Alimanovic, and other subsequent cases. The Court clearly no longer considers that it its role is to create teleological concepts such as 'genuine links' or 'sufficient degrees of integration' to determine the rights of applicants directly under the Treaties. Instead, all that is required is a strict reliance on the normal meaning of the wording contained in Directive 2004/38. From this perspective, the decisive and exclusive reference to Directive 2004/38 has contributed to legal certainty and is judicially coherent and in fact the comparative lack of attention in the recent discussion on the Ziótkowski and Förster cases, at least when compared to Dano, is surprising. ${ }^{100}$

Whilst interesting for academic debate and providing a lot of room for manoeuvre for lawyers, the vague formulas described in Step 2 above were next to useless in daily administrative practice. As Shuibhne notes, "case-by-case assessments are far from perfect, especially from the perspectives of legal certainty and workability".101 They give very little guidance as to precisely when a claim can be denied. ${ }^{102}$ This makes it difficult for authorities to know exactly when they can legally deny a claim to protect integrity of the national welfare system, something that was always permissible, at least in theory, according to

99 A notable exception being Court of Justice, judgment of 19 June 2014, case C-507/12, Saint Prix, where the Court held that a women could retain the status of worker after leaving work due to the "physical constraints of the late stages of pregnancy" as long as she returns to work within "a reasonable period" - see hereunder.

100 See on the development of case law and the importance of this judgment, Šadl, U., and Sankari, S. (2017). Why did the Citizenship Jurisprudence Change?, p. 91-109.

101 Nic Shuibhne, N. (2015). Limits Rising, Duties Ascending: The Changing Legal Shape of Union Citizenship, cit., p. 913.

102 Schmidt, S.K. (2017). Extending Citizenship Rights and Losing it All: Brexit and the Perils of 'Over-Constitutionalization'. In: Thym, ed., Questioning EU Citizenship - Judges and the Limits of Free Movement and Solidarity in the EU. Oxford: Hart Publishing, p. 19, 23. 
the Court. ${ }^{103}$ As the Court has explained, the shift in approach was indeed to create a more legally certain system. In Alimanovic and Garcia Nieto, the Court asserts that the German rule at hand enables those concerned to know "without any ambiguity, what their rights and obligations are", and as such guarantees "a significant level of legal certainty and transparency in the context of the award of social assistance". 104 The idea is that creating strict identifiable rules, rather than vague formulas is beneficial for national administrators and applicants alike as everyone knows where they stand. Member State legislators are also reassured since the Förster case, as mentioned above, that if they comply with the words of the Directive, their implementation and decisions taken based on it will not be second-guessed by the Court of Justice as they were in the past.

From this perspective, one way in which the Dano decision is 'revolutionary' is that it constitutes a reversal of the system as it was previously understood, whereby Member States would engage on the "thorny path" of granting social benefits but then subsequently expelling EU citizens that become a burden on the social system of the host-Member State. Instead, now Member States may now withhold equal treatment from "any category" of European citizens making use of their free movement rights. ${ }^{105}$ This is a valid critique, and indeed this article will discuss in the following section some of the implications of the Court's reasoning in terms of determining when an individual has sufficient resources and/or is an unreasonable burden. However, it should initially be emphasised that in Dano it was already established in the facts of the case that the applicant did not have a right to reside under the Directive. ${ }^{106}$ As such, the Court was merely called upon to ask whether these individuals should be entitled to rely on the principle of equal treatment under Article 24. The Directive is clear that this provision is only available to those citizens "residing on the basis of this Directive". Moreover, unlike Article 6 residence which should not be lost "as long as they do not become an unreasonable burden", Article 7 residence is only valid "as long as they meet the conditions set out therein".107 This approach would also conform with the analysis of whether individuals meet the conditions for permanent residence under Article 16(1). Lastly, it has

103 Grzelczyck, cit. paras. 42-43; see also Šadl, U., and Sankari, S. (2017). Why did the Citizenship Jurisprudence Change?, cit., p. 98.

104 Alimanovic, cit., para. 61; Garcia Nieto, cit., para. 49.

105 Schiek, D. (2017). Perspectives on Social Citizenship in the EU: From Status Positivus to Status Socialis Activus via Two Forms of Transnational Solidarity, cit., p. 361 .

106 Dano, cit., para. 44.

107 See Article 14 Directive 2004/38 on the Retention of a Right of Residence. 
to be questioned whether being able to make a claim for social assistance but having the possibility of it being rejected without losing a right to reside is really a worse situation for the individual in question, rather than automatically being entitled to social assistance only to subsequently find that granting this granting has resulted in their residence status being rescinded entirely and an expulsion order made against them?

The Consequences of the Evolution: beyond the Dano-Trilogy

The Marginalization of the Precariat and the Janus-Faced Approach of the Court

The five-step evolution explained above is for the most part judicially coherent, and the increase in legal certainty can be seen as a positive development. Yet, there are certain consequences that are problematic. It cannot be emphasised enough that a direct consequence is the potential exclusion from legal residence and equal treatment of various vulnerable groups of EU citizens. A system that focusses almost exclusively on legal stay under Article 7 Directive 2004/38 will inherently have the same built-in bias for economically active and wealthier individuals as the Directive itself. Economically active individuals, as the original actors on the common and then internal market, have always had a privileged position over economically inactive EU citizens. ${ }^{108}$ This differentiation is deeply ingrained in EU free movement rights, and leads to situations where EU law distinguishes between the 'good' or 'deserving' citizen on the one hand, and the 'bad' or 'undeserving' ones on the other hand. ${ }^{109}$ This means that the Directive falls short of being a tool for positive citizenship, or receptive solidarity, which argues that in order to achieve equality and fully realise social citizenship individuals, particular more vulnerable groups of persons, require positive rights such as welfare entitlement. ${ }^{110}$ Instead, the conditional nature of Directive 2004/38 results in the potential exclusion from protection of those EU Citizens who in fact would need protection the most.

108 See Nic Shuibhne, N. (2010). The Resilience of EU Market Citizenship. Common Market Law Review 47 (4), pp. 1597-1628; O'Brien, C. (2016). Civis Capitalist Sum: Class as the New Guiding Principle of EU Free Movement Rights. Common Market Law Review 53 (4), pp. 937-978.

109 Nic Shuibhne, N. (2015). Limits Rising, Duties Ascending: The Changing Legal Shape of Union Citizenship, cit., p. 928.

110 Schiek, D. (2017). Perspectives on Social Citizenship in the EU: From Status Positivus to Status Socialis Activus via Two Forms of Transnational Solidarity, cit., p. 349. 
This arguably goes against the very idea of 'citizenship' as a philosophical concept and the creation of 'equality' between all fellow-citizens as one of its central tenets. EU citizenship, as Kochenov writes, "virtually never protects the weak and the needy" based on their human needs alone. As such, it does not empower but merely informs the "dogmatic ideal of a good market citizen".111 In a cruel irony, EU Citizenship rights become available only for those "who do not need them and only when they do not need them".112 This becomes even more problematic as, as other scholars have rightly pointed out, EU Citizens falling foul of such strict conditionality will most likely be minority groups; women and disabled persons; ${ }^{113}$ and low-pay, marginal workers. ${ }^{114}$ In other words, those already on the margins of society are stigmatised even more as 'undeserving' and stand to lose out most in terms of residence and equal treatment rights.

In practice, this doctrinally defensible stance may not just lead to the granting or denial of a social benefit, but can result in unlawful residence and even social exclusion. This is particularly so because those who do not meet the requirements laid down in Directive 2004/38 will not only be denied equality as regards access to social benefits, but can be held to fall outside the scope of EU law entirely if their social benefit claim is denied because their residence is deemed illegal under article 7 Directive 2004/38. In some cases, these individuals will become 'tolerated' citizens, ${ }^{115}$ who are not or cannot be expelled but whose legal status is nevertheless technically irregular. They may form a class of "illegal migrants, living unlawfully in other Member States without equal treatment guarantees". 116 This EU Lumpenproletariat ${ }^{117}$ has no right to residence and equal treatment, and even no rights under the Charter of

111 Kochenov, D. (2017). The Citizenship of Personal Circumstances in Europe. In: Thym, ed., Questioning EU Citizenship - Judges and the Limits of Free Movement and Solidarity in the EU. Oxford: Hart Publishing, p. 51.

112 Minderhoud P., and Mantu, S. (2017). Back to the Roots? No Access to Social Assistance for Union Citizens who are Economically Inactive, cit., p. 207.

113 O'Brien, C. (2017). United in Adversity: EU Citizenship, Social Justice and the Cautionary Tale of the $U K$, cit., pp. 92-102.

114 O'Brien, C., Spaventa, E., and De Coninck, J. (2015). The concept of worker under Article 45 TFEU and certain non-standard forms of employment, cit.; O'Brien, C. (2017). United in Adversity: EU Citizenship, Social Justice and the Cautionary Tale of the UK, cit., pp. 149-159.

115 Nic Shuibhne, N. (2015). Limits Rising, Duties Ascending: The Changing Legal Shape of Union Citizenship, cit., pp. 926-927.

116 Thym, D. (2015). When Union citizens turn into illegal migrants: the Dano case, cit.

117 Schiek, D. (2017). Perspectives on Social Citizenship in the EU: From Status Positivus to Status Socialis Activus via Two Forms of Transnational Solidarity, cit., p. 36o. 
Fundamental Rights as they fall outside the scope of application of EU Law, ${ }^{118}$ a (non-)status so far unknown in EU Law.

On the other hand, cases like Gusa, ${ }^{119}$ Saint-Prix,${ }^{120}$ and Dakneviciute, ${ }^{121}$ suggest that the Court is not seeing the Directive as a tool to 'cut-off' rights for EU Citizens in need. All these cases concerned dealt with entitlements of EU Citizens under Directive 2004/38 after they became unemployed of incapable of continuing to work as self-employed persons. The problem was, that the Directive wording of the Directive was unclear about retention of rights of selfemployed persons, see Gusa, or workers or self-employed persons, who could not continue their economic activity due to pregnancy, see Saint-Prix and Dakneviciute respectively. In all cases the Court ensured that the citizen could retain worker status through an interpretation of the Directive or reference to art. 45 TFEU itself, if the Directive would not resolve the situation satisfactorily, is vaguely formulated, or, as was the case in Saint-Prix and Dakneviciute, ${ }^{122}$ simply does not deal with pregnancy as a cause for ceasing economic activity is significant. It is important to emphasize, however, that all three applicants were economically active before and wanted to retain their status; the cases did not concern access to legal residence and, as a consequence, equal treatment as regards access to social benefits under Directive 2004/38.

\subsection{Increasing Rights for Some under Directive 2004/38}

That being said, the denial of equal rights to access social assistance and problematic rights of residence to EU Citizens who have never worked, have no intention to work, and have no independent funds at their disposal, as in Dano, is quite normal. ${ }^{123}$ Furthermore, criticism that the European Union is a 'rich person's club' that only benefits the affluent few over the many is hardly a novel critique and omits the fact that the freedoms enjoyed by all EU Citizens on the internal market go far beyond anything available in other legal regimes. Such developments do not signal that the Court has 'abandoned' EU citizens, as is

118 As the Court made explicit in Dano, cit., paras. 89-91; See Nic Shuibhne, N. (2015). Limits Rising, Duties Ascending: The Changing Legal Shape of Union Citizenship, cit., pp. 914-915.

119 Court of Justice, judgment of 20 December 2017, case C-442/16, Gusa v. Ireland.

120 Court of Justice, judgment of 19 June 2014, case C-507/12, Jessy Saint-Prix.

121 Court of Justice, judgment of 12 September 2019, case C-544/18, UK v. Dakneviciute.

122 See, Saint-Prix, cit., paras. 26-39 and Dakneviciute, cit., paras. 27-30.

123 Davies, G. (2018). Has the Court changed, or have the cases? The deservingness of litigants as an element in Court of Justice citizenship adjudication, cit. See also on this issue Nic Shuibhne, N. (2010). The Resilience of EU Market Citizenship, cit. 
suggested. ${ }^{124}$ In fact, the exclusive focus on Directive 2004/38 by the Court has a Janus-face. Whilst Dano and Alimanovic can be seen as, on balance, reducing the rights available to EU citizens, there are other cases wherein a strict application of the Directive actually lead to an increase of rights for EU Citizens. For example, in Metock, ${ }^{125}$ differentiations between family reunification and family formation, which were allowed under the pre-Directive Akrich case, ${ }^{126}$ were ruled out by the CJEU because such differentiations would not re-appear in Directive 2004/38. ${ }^{127}$ The EU legislator refrained from codifying the Akrich rule in Directive 2004/38 and therefore Member States were prohibited from applying it. Whilst Metock is mostly seen as a decision which fits with the classic paradigm of cases in which the CJEU gradually strengthens the rights of EU citizens, ${ }^{128}$ such analysis overlooks the decisive and exclusive dominance the Court awarded to rules and conditions contained in Directive 2004/38 in its judgment, particularly emphasizing the choices made by the EU legislator.

Another case which fits into this line is the recent case of Coman. This decision was widely applauded for recognizing the rights of same-sex spouses, married in a Member State allowing for same-sex marriages, to travel and reside with their partner throughout the EU, including return to the home state. ${ }^{129}$ The Court reasons that Directive 2004/38, which applies in analogy in situations or return to the home state, ${ }^{130}$ would allow the Member States leeway as regards the recognition of 'registered partnerships' entered into in other Member States only. The recognition of these are 'subject to national

124 Nic Shuibhne, N. (2015). Limits Rising, Duties Ascending: The Changing Legal Shape of Union Citizenship, p. 936.

125 Court of Justice, judgment of 25 July 2008, case C-127/08, Metock and Others.

126 Court of Justice, judgment of 23 September 2003, case C-109/o1, Akrich.

127 See about this practice of 'gold-plating', Valcke, A. (2019). EU Citizens' Rights in Practice: Exploring the Implementation Gap in Free Movement Law. European Journal of Migration and Law 21, pp. 289-312, $297 \mathrm{ff}$.

128 Minderhoud P., and Mantu, S. (2017). Back to the Roots? No Access to Social Assistance for Union Citizens who are Economically Inactive, cit., p. 192; see also Nic Shuibhne, N. (2015). Limits Rising, Duties Ascending: The Changing Legal Shape of Union Citizenship, cit., p. 989 .

129 Court of Justice, judgment of 5 June 2018, Case C-673/16, Coman, para. 25; Court of Justice, judgment of 12 March 2014, case C-456/12, $O \& B$, paras. 50, 61 .

130 This builds upon the 'Singh principle', which states that EU rights "cannot be fully effective if such a person may be deterred from exercising them by obstacles raised in his or her country of origin to the entry and residence of his or her spouse ... when a Community national who has availed himself or herself of those rights returns to his or her country of origin, his or her spouse must enjoy at least the same rights of entry and residence as would be granted to him or her under Community law", Court of Justice, judgment of 7 July 1992, case C-370/9o, Singh, para. 23; see also, $O \& B$, cit. 
law'. However, no such reference to national law is made in the Directive as regards the term 'spouse'. The Court in Coman focussed solely on the wording of Article 2 Directive 2004/38, finding that Member States cannot rely on national legislation as regards the recognition of a marriage entered into in another Member State. ${ }^{131}$ The analogous and strict application of Directive 2004/38 is also beneficial for 'returning citizens' who since its adoption have found that their conditions of entry "should not, in principle, be more strict than those provided for by Directive 2004/38".132

The fact that the Metock, and Coman, cases are simultaneously characterised as 'rights-enhancing' judgments, while Förster, Ziótkowski, Dano and Alimanovic are seen as diminishing rights, but all nevertheless share Directive 2004/38 as the exclusive framework within which the Court establishes legal residence and integration shows the Janus-faced results of the evolution of Court's case law. On the one hand, access to rights is made stricter with reference to legal residence under Directive 2003/38 exclusively, while on the other hand, the reach of rights obtained when residence is legal under the Directive is increased. The Court is in fact building a legally certain and coherent system of assessing legal residence and access to rights for EU Citizens based on the provisions of Directive 2004/38 alone, even if its application means some EU citizens lose out. ${ }^{133}$

\subsection{Less Room for Individual (Proportionality) Assessments and Automatic Findings of Illegality}

The Court's approach to interpreting Directive 2004/38 has been criticised for denying applicants individual proportionality assessments in their cases. This is particularly so when determining whether the burden placed by that specific EU citizen is 'reasonable' or 'unreasonable.'134 In this regard, the Court has

131 Coman, cit., para. 36. Thereafter the Court looks at potential justifications of a restriction to free movement of persons and holds them all to be inapplicable.

132 See in this regard $O \& B$, cit., paras. 50, 61, with reference to Singh, cit., para 20: "He would in particular be deterred from (exercise his free movement rights) if his spouse and children were not also permitted to enter and reside in the territory of his Member State of origin under conditions at least equivalent to those granted them by Community law in the territory of another Member State"; Court of Justice, judgment of 14 November 2017, case C-165/16, Lounes, paras. 6o-61; Court of Justice, judgment of 10 May 2017, case C133/15, Chavez-Vilchez, para. 55; Court of Justice, judgment of 12 July 2018, case C-89/17, Banger, para. 35 .

133 As mentioned before the Court actively interprets the Directive in favor of applicants, for example in case of family life and children adopted under the Algerian Kafala system, see Court of Justice, judgment of 26 March 2019, case C-129/18, S.M. v. UK.

134 As the Court formulated in Grzelczyk and other cases; see O'Brien, C. (2017). United in Adversity: EU Citizenship, Social Justice and the Cautionary Tale of the UK, cit. 
completely departed from its individualistic test last used in Brey, ${ }^{135}$ which was held to be "unworkable" and redundant. ${ }^{136}$ Instead, it has opted for a more 'systemic' test in Alimanovic, ${ }^{137}$ which asserts that that a single applicant for welfare benefits could 'scarcely be described as an 'unreasonable burden', however, the accumulation of all the individual claims which would be submitted to it would be bound to do so". ${ }^{138}$ In doing so, it has been claimed that the status of individual assessments is "radically downgraded",139 and that proportionality / individual assessments have not been "set to work" as was the case in earlier cases. ${ }^{140} \mathrm{O}$ 'Brien is strongest in her criticism claiming that the Court uses "a sledgehammer to crack an already cracked nut", ${ }^{141}$ by deciding the cases without any regard given to sufficient resources or applying proportionality "at any stage" in either Dano or Alimanovic. ${ }^{142}$

It is true that in both Dano and Alimanovic there was a distinct lack of individual assessment as to the position of the applicants at hand. However, in Dano the Court was merely determining whether those already deemed to be without sufficient resources, as the referring court had already established, could under the Directive rely on the principle of equal treatment to claim social assistance. ${ }^{143}$ In this situation, the Court did emphasise that her the financial situation should be specifically examined without taking into account the benefit claimed. ${ }^{144}$ The Court did not, however, feel the need to consider the reasonableness of Ms Dano's burden. This omission is strange especially as Ms Dano is a stark example of an individual that is not entitled to social assistance or residence rights under EU law, ${ }^{145}$ as she only entered Germany to

\footnotetext{
135 see Section II.2 above.

136 O'Brien, C. (2017). United in Adversity: EU Citizenship, Social Justice and the Cautionary Tale of the UK, cit., p. 49; see also O'Brien, C. (2017). The ECJ Sacrifices EU citizenship in vain: Commission v United Kingdom, cit., p. 216.

137 To use the terminology as applied by Thym, D. (2015). The Elusive Limits of Solidarity: Residence Rights of and Social Benefits for Economically Inactive Union Citizens, cit.

138 Alimanovic, cit., para. 62.

139 Nic Shuibhne, N. (2015). Limits Rising, Duties Ascending: The Changing Legal Shape of Union Citizenship, cit., p. 913.

140 Davies, G. (2018). Has the Court changed, or have the cases? The deservingness of litigants as an element in Court of Justice citizenship adjudication, cit., p. 1445.

141 O'Brien, C. (2017). United in Adversity: EU Citizenship, Social Justice and the Cautionary Tale of the $U K$, cit., p. 49 .

142 Ibid, p. 51, 55 .

143 Dano, cit., para. 44.

144 Dano, cit., para. 8o.

145 Davies, G. (2018). Has the Court changed, or have the cases? The deservingness of litigants as an element in Court of Justice citizenship adjudication, cit., p.1454.
} 
obtain social assistance despite the fact she did not have sufficient resources to claim a right of residence. ${ }^{146}$

In Alimanovic again the Court did not assess the individual situation of the applicants, and nor did it test the German rule against the principle of proportionality after finding that it was in conformity with the wording of the Directive 2004/38. This approach differs indeed from earlier cases, such as Baumbast, which was decided under article $18 \mathrm{EC}$ (now Article $21 \mathrm{TFEU}$ ) and outside the scope of Directive 90/364. Back then, the Court held that any limitations to that Treaty right must be in accordance with the general principle of proportionality. ${ }^{147}$ In Alimanovic, however, the legal situation under Article 45 TFEU received little attention. ${ }^{148}$ The Court held that the Directive itself established a system which considers various factors, guarantees a significant level of legal certainty, and complies with the principle of proportionality. ${ }^{149}$ Whilst it is not clear just how many 'various factors' Directive 2004/38 actually considers, ${ }^{150}$ the comparison between Alimanovic and Baumbast is not entirely appropriate. As explained above and unlike Directive 90/364, Directive 2004/38 has as its legal bases both Articles 45 and $18 \mathrm{TFEU}$, and sets minimum standards on EU Citizens' rights including retaining worker status, which the Member States cannot go below. A literal interpretation and application of this Directive should not be seen as disproportionate in the context outlined above. ${ }^{151}$ As such, the Court's decision to apply the standards and conditions codified by the EU legislator based on several legal bases in Directive 2004/38 is a coherent interpretation of the rules in force. The message for the Member State remains the same since the Förster decision: a word-by-word implementation of the Directive will not be second guessed by the Court.

That is not to say that the lack of individual proportionality assessments is unproblematic. It carries the danger of endorsing, albeit tacitly, national systems which employ circular arguments permitting authorities to either block economically inactive EU citizens from obtaining certain social benefits, or at least allowing said authorities to systematically check individuals' residence status upon their application for social assistance. Every application for social benefits might in such a situation automatically lead to an assessment of legal

\footnotetext{
146 Dano, cit., para. 78.

147 O'Brien, C. (2017). United in Adversity: EU Citizenship, Social Justice and the Cautionary Tale of the $U K$, cit., p. 42-43.

148 Ibid, p. 51.

149 Alimanovic, cit., para. 61.

150 Article 7(3), the Article that decided Alimanovic, is being based almost exclusively on time spent in genuine employment.

$15^{1}$ See section II.6. above.
} 
residence of the applicant under Directive 2004/38, which in turn might lead to a finding of 'illegal residence' under the Directive. ${ }^{152}$ As Thym notes, the Dano decision can be understood as meaning that "any recourse to social assistance pre-empts legal residence status", as is the case in Germany. ${ }^{153}$ Indeed, without any kind of assessment of individual circumstances, the mere application for social assistance is potentially enough to exclude their eligibility for such benefits as this by itself demonstrates their lack of resources. ${ }^{154}$ Moreover, whilst Ms Dano was denied a SG B II (Jobseeker) benefit as she was not actively looking for work and only entered Germany in order to claim social assistance benefits, Alimanovic also concerned SGB II (Jobseeker) benefits, and yet the applicants who were actively seeking employment were again denied such benefits due to the exception contained in Article 24(2). This reasoning means that SGB II (Jobseekers) benefits are seemingly inaccessible to all economically inactive EU citizens. ${ }^{155}$

Another clear example of this circular reasoning can be seen in Commission $v U K,{ }^{156}$ which concerned the legality of the UK's 'habitual residence test', that effectively imposes an Article 7 right-to-reside test upon claimants before granting Child Benefit and Child Tax Credit social benefits. The Commission claimed this legal test was not permitted under Article 11(3)(c) of Regulation $883 / 2004$, which imposed solely a factual test of residence. However, the Court found that Regulation 883/2004 does not harmonise the conditions for granting social security benefits, and that the UK right-to-reside test was an "integral part" of the eligibility criteria for these social benefits, which is outside the scope of the Regulation. ${ }^{157}$ Part of the Commission's complaint was that by checking individuals' residence status upon application for the benefits in question, this constituted "systematic checking" of individuals residence status, prohibited under Article 14(2) Directive 2004/38. However, the Court disagreed with this. ${ }^{158}$ The decision has been criticised strongly by O'Brien, who

152 Thym, D. (2015). The Elusive Limits of Solidarity: Residence Rights of and Social Benefits for Economically Inactive Union Citizens, cit.

153 Ibid, p. 42.

154 Although, it should be emphasized that whilst Ms Dano was excluded from social assistance benefits, she continued (before and after the decision) to receive Child Benefit (social security) for her son, which was unaffected by her social assistance claim.

155 O'Brien, C. (2017). United in Adversity: EU Citizenship, Social Justice and the Cautionary Tale of the UK, cit., pp. $53^{-56}$.

156 Court of Justice, judgment of 14 June 2016, case C-308/14, Commission v. United Kingdom.

157 Commission v. United Kingdom, cit., para. 69. See also O'Brien, C. (2017). The ECJ Sacrifices EU citizenship in vain: Commission v United Kingdom, cit., p. 221.

$15^{8}$ Commission v. United Kingdom, cit., para. 84. 
claims that the UK procedures essentially mean that no economically inactive EEA migrant, who is applying for social benefits, can ever have a right to reside, because "any benefit application is deemed to dissolve any claim to selfsufficiency". ${ }^{159}$ In other words, the mere application for social benefits results in a finding that the EU citizen in question does not have a right-to-reside under Article 7 Directive 2004/38. Furthermore, "there is no starting presumption of lawful residence, or starting position of citizenship-based eligibility that is then limited and in some cases checked". ${ }^{160}$ In fact, the individual's status is checked purely because they apply for such a benefit, meaning in effect there is actually a presumption of illegality. Given that a rejection of the social benefit results in the individual being outside the scope of application of the EU free movement rules, ${ }^{161}$ the UK system is likely to have a chilling effect on social benefit claims by economically inactive EU citizens, disproportionality affecting some of the most vulnerable persons in society.

\subsection{The Ever Increasing Scope of 'Social Assistance' under Directive $2004 / 3^{8}$}

The formalised approach of the Court and the new status of the Directive has also impacted upon the range of social benefits that can be subjected to a right-to-reside test on the basis of Article 7 Directive 2004/38. Directive 2004/ 38 itself only refers to 'social assistance', with 'social security' benefits being coordinated by Regulation 883/2004 and its predecessors. Given that the 2004 Regulation as opposed to earlier versions, which only applied to workers, also applies to "the new category of non-active persons", ${ }^{162}$ it was considered that Regulation 883/2004 would apply to anyone subject to the legislation of one or more Member states, regardless of economic activity. ${ }^{163}$ The Regulation was

\footnotetext{
159 O'Brien, C. (2017). The ECJ Sacrifices EU citizenship in vain: Commission v United Kingdom, cit., p. 212.

160 Ibid.

161 See Thym, D. (2015). The Elusive Limits of Solidarity: Residence Rights of and Social Benefits for Economically Inactive Union Citizens, cit., p. 21.

162 Recital (42) Regulation $883 / 2004$ on the coordination of social security systems, OJ L 166, 30.4.2004, p. 1-98; See O'Brien, C. (2017). The ECJ Sacrifices EU citizenship in vain: Commission v United Kingdom, cit., p. 222.

163 Article 2, Regulation 883/2004; see also Article 11 of Implementing Regulation No 987/2009 laying down the procedure for implementing Regulation (EC) No 883/2004 on the coordination of social security systems, OJ L 284, 30.10.2009, p. 1-42; see also Internal Labour Organisation (2010). Coordination of Social Security Systems in the European Union: An explanatory report on EC Regulation No 883/2004 and its Implementing Regulation No 987/ 2009. Switzerland: International Labour Office, p.7.
} 
considered to be triggered by a factual test of residence, rather than a legal test of lawful residence. ${ }^{164}$

The cases of Brey, Dano, Alimanovic and Garcia-Nieto all concerned 'special non-contributory cash benefits'. Whilst not classified as 'social security' in the strict sense, these benefits are included under Article 70 Regulation 883/ 2004, and are suggested to have the nature of both social security and social assistance. ${ }^{165}$ In these cases the Court rejected the European Commission's initial argument that social assistance, and consequently right-to-reside tests on the basis of Directive 2004/38, could only be applied to social benefits not mentioned in Regulation 883/2004 and therefore outside its scope of application. ${ }^{166}$ Rather, it held that social assistance should have its own definition under EU law and that special non-contributory cash benefits met this definition. ${ }^{167}$ In the aforementioned Commission v United Kingdom case, the Court was confronted with the application of a right-to-reside test to Child Benefit and Child Tax Credits. These were clearly not special non-contributory cash benefits, ${ }^{168}$ but rather fell under Chapter 8 of Regulation 883/2004 on Family Benefits and "must be regarded as social security benefits". ${ }^{169}$ However, the Court still held that there is "nothing to prevent, in principle, the grant of social benefits to Union citizens who are not economically active being made subject to (a right to reside test)". ${ }^{170}$ According to the Court, the applicants failed to fulfil the conditions of entitlement of the benefit. The Court's reasoning suggests that potentially any social benefit, so long as it has some characteristics of social assistance, such as being taxpayer funded or non-contributory in nature, can be subjected to a right-to-reside on the basis of Article 7 Directive 2004/38, regardless of the benefit's classification under Regulation 883/2004. ${ }^{171}$

The application of Article 7 criteria to social security benefits has been criticised for undermining the political compromise at the heart of both pieces of

164 Verschueren, H. (2013). Free Movement or Benefit Tourism: The Unreasonable Burden of Brey. European Journal of Migration 16 (2), pp. 147-79.

165 See Opinion of Advocate General Wahl delivered on 29 May 2013, case C-14o/12, Brey, para. 48.

166 See Brey, cit., para. 48.

167 Brey, cit., paras. 58-59.

168 Indeed, the original complaint included special non-contributory cash benefits, but these were removed following the Brey and Dano decisions. See Commission v. United Kingdom, cit., para. 27.

169 Commission v. United Kingdom, cit., para. 6o.

170 Commission v. United Kingdom, cit., para. 68.

171 Commission v. United Kingdom, cit., para. 51. See also O'Brien, C. (2017). The ECJ Sacrifices EU citizenship in vain: Commission v United Kingdom, cit., p. 220. 
legislation adopted in 2004 as well as the differentiation between the two types of social benefits that flow from it. ${ }^{172}$ Furthermore, in Commission $v$ United Kingdom the Court relies upon paragraphs 83 of Dano and 44 of Brey to come to this conclusion. However, both cases concern special non-contributory cash benefits, which are a special category within Regulation 883/2004. The Court ignores the differentiation of benefits within the Regulation and applied them as if there was one general rule applicable to all social benefits. As a result, the conflation of the two legal instruments makes the equal treatment provision in Article 4 Regulation 883/2004 almost redundant. ${ }^{173}$ At the same time, the Court has made relying on the equality clause in Article 24 of Directive 2004/38 difficult in cases involving applications for social security benefits for inactive EU Citizens regardless of the status of the benefit in question under Regulation 883/2004. Potentially all applications for social benefits can be subjected to a right-to-reside test, with all problems attached to the circular application of such tests outlined in the previous section.

\section{Conclusion}

Contrary to what is sometimes claimed, this article has made the argument that the Court is not working to "advantage the few, excluding the many".174 Recognising that the Court is caught between a "rock and a (very) hard place", ${ }^{175}$ and unable to please everybody, it has been shown that at least for the most part the Court's reasoning is logical and judicially coherent. The development of legal residence and accessing social benefits has developed from the initial introduction of secondary legislation, to the establishment of Union Citizenship, and the adoption and interpretation of Directive 2004/38 through five major steps. Where this chapter departs from much other scholarly opinion is by asserting that in fact the major factor in the Court's evolving approach is the adoption and subsequent implementation, application, and interpretation of Directive 2004/38. In this respect, the Court is merely following its traditional

\footnotetext{
172 Verschueren, H. (2013). Free Movement or Benefit Tourism: The Unreasonable Burden of Brey, cit., pp. 159-165; see also O'Brien, C. (2017). The ECJ Sacrifices EU citizenship in vain: Commission v United Kingdom, cit.

173 O'Brien, C. (2017). United in Adversity: EU Citizenship, Social Justice and the Cautionary Tale of the $U K$, cit., p. 51 .

174 Spaventa, E. (2017). Earned Citizenship - Understanding Union Citizenship through Its Scope, cit., p. 223 .

175 Nic Shuibhne, N. (2015). Limits Rising, Duties Ascending: The Changing Legal Shape of Union Citizenship, cit., p. 916.
} 
method of interpreting EU rules by sticking to a formal, textual interpretation of the law following the adoption of secondary legislation. Criticism that the Court is re-establishing the dichotomy between economically active and inactive individuals often misses the point that these differences are clearly manifest in Directive 2004/38, which also adds categories of citizens who benefit from equal treatment without economic activity, such as persons with sufficient means and permanent residents. The Directive has been interpreted to create a closed system for the definition of legal residence whereby, with very limited exceptions, only residence that is considered lawful under the Directive itself will be accepted by the Court. Only legal residence as defined by the Directive can lead to permanent residence, as stated in Ziótkowski, and only such legal residence gives access to equal treatment with Member State nationals, as can be seen in Dano and Alimanovic. Yet, this exclusive reference to the Directive can also be beneficial for other groups of EU Citizens, as for example the Metock and Coman cases have shown.

The reliance on Directive 2004/38 has changed the dynamics of law governing EU Citizenship. First, as has been shown, the Court is building a coherent and simplified approach to rights enjoyed by EU Citizens based on a strict interpretation of Directive 2004/38. This will increase legal certainty for applicants and national authorities involved in decision making. Second, by following the wording of the Directive and accepting literal implementations of the Directive by the Member States since the Förster case, the Court has achieved two things. It has assured Member States that their implementation of the Directive, if true to its wording, is safe from being second guessed by the Court on grounds of primary law. Member States can always provide more rights than prescribed by the Directive, however, they will not be forced to do so. In addition, the Court has taken itself out of the line of fire in the sensitive political discussions about access to social benefits for (economically inactive) EU Citizens. It may be that the Court is suffering from "a certain degree of "citizenship exhaustion" and has "put the brakes on a liberal interpretation of free movement rights". ${ }^{16}$ After decades of acting as the motor for European integration in the field of EU citizenship, the Court might reasonably now believe that its job is done and that further developments have to be driven by all political actors in the new governance structures created by the Treaty of Lisbon. ${ }^{177}$ Moreover, it could be argued that the Court does not see the core of Union citizenship in residence and access to social welfare of economically

\footnotetext{
176 Sarmiento D., and Sharpston, E. (2017). European Citizenship and Its New Union: Time to Move on? In: Kochenov, ed., EU Citizenship and Federalism - The Role of Rights, cit., p. 229.

177 Ibid, p. 230, 241.
} 
inactive Citizens, but in 'constitutional principles' such as "the protection of fundamental rights, the development of democracy, and the Rule of Law".178 Notwithstanding a poor attempt at playing politics by intervening in the Brexit debate by releasing the Commission $v$ United Kingdom judgment one week before the referendum, ${ }^{179}$ the Court seems much less willing to 'legislate' in this area in addition to the European legislator. Instead, it persistently defers back to the words approved by Council and Parliament in Directive 2004/38. When compared to other issues connected to Citizenship, such as the need to preserve the legal position and ensure the continuity of rights for the four million UK nationals and EU Citizens potentially affected by Brexit, ${ }^{180}$ cases concerning social assistance claims by economically inactive citizens can seem marginal. Furthermore, the fully justified criticism of the law as it stands may be more wisely directed at the EU legislator, and future improvements to the precarious situation of Union Citizens should be expected foremost from amendments and/or revisions to Directive 2004/38, as opposed to expecting developments to arise solely from the Court.

\footnotetext{
178 Ibid, p. 227 .

179 O'Brien, C. (2017). The ECJ Sacrifices EU citizenship in vain: Commission v United Kingdom, cit., p. 209.

180 See Court of Justice, judgment of 10 December 2018, case C-621/18, Wightman, para. 64 .
} 